\title{
Pathology of circulating tumor cells and the available capture tools (Review)
}

\author{
YIBING GUAN, FANGSHI XU, JUANHUA TIAN, HONGWEI CHEN, CHUANCE YANG, \\ SHANLONG HUANG, KE GAO, ZIYAN WAN, MINGRUI LI, MINXIN HE and TIE CHONG
}

Department of Urology, The Second Affiliated Hospital, School of Medicine, Xi'an Jiaotong University, Xi'an, Shaanxi 710004, P.R. China

Received November 6, 2019; Accepted February 14, 2020

DOI: $10.3892 /$ or.2020.7533

\begin{abstract}
Circulating tumor cells (CTCs), are tumor cells that diffuse into the circulating blood and serve an important role in the progress of cancer. During the early stages of cancer, CTCs undergo an epithelial-mesenchymal transition and obtain a more invasive phenotype. Subsequently, the tumor cells enter the circulating blood with the aid of immune cells, and enter a dormant state upon reaching distal organs. As the tumor progresses, metastasis may occur under certain conditions. The capture technologies available for CTCs are based on antibody-based capture, or capture based on the physical properties of CTCs, as well as modern technologies that integrate both these methods. Emerging modern technologies have increased the accuracy and efficiency of tumor cell capture, and have thus improved our understanding of tumor cells, and the molecular mechanisms underlying their properties. CTCs serve an important role in disease progression, prediction of patient prognosis and individualized treatment.
\end{abstract}

\section{Contents}

1. Introduction

2. Physiological processes of CTCs

3. Isolation and detection of CTCs

4. CTC associated research methods

5. Conclusion

\section{Introduction}

The metastasis of cancer is a complex procedure, ultimately resulting in patient death (1). During metastasis, malignant

Correspondence to: Professor Tie Chong, Department of Urology, The Second Affiliated Hospital, School of Medicine, Xi'an Jiaotong University, 157 Xiwu Road, Xi'an, Shaanxi 710004, P.R. China

E-mail: chongtie@126.com

Key words: circulating tumor cells, metastasis, pathology, separation, detection, application tumor cells detach from the primary tumor and enter the circulatory system during the early stages of cancer, and when these circulating tumor cells (CTCs) reach a distal organ, they enter a dormant state or form a metastatic tumor (2-4). Metastasis contributes to $\sim 90 \%$ of all cancer-associated deaths $(5,6)$. In recent years, with advances in capture and identification technologies, our understanding of CTCs and the associated mechanisms underlying their action has become more accurate. In 2017, the American Joint Committee on Cancer included the presence of CTCs in the MO(i+) classification stage in breast cancer (7). CTCs represent the metastatic capacity of cancer, and may allow for an earlier diagnosis compared with imaging and clinical evidence. Thus, in the present review the physiological processes, of CTCs including, engendering and spread to distant organs, and the analytical tools available, as well as CTC research methods are described.

\section{Physiological processes of CTCs}

Tumor cells gain invasive ability and enter the circulatory system. CTCs arise from the tumor cells of primary tumors, metastases, lymph nodes or disseminated tumor cell pools $(5,8)$. Before tumor cells enter the circulating system, a series of phenotypical and genotypical changes occur, including cytoskeletal reorganization, protease secretion, changes to the expression profile of adhesive proteins and receptors, and these changes allow CTCs to acquire an invasive phenotype and detach from the primary tumor (Fig. 1A) (9,10). Epithelial-mesenchymal transition (EMT) serves a key role in the loss of cell polarity and decrease of cell-cell adhesion resulting in an increase in the invasiveness of tumor cells $(11,12)$. Predisposing factors of EMT include transforming growth factor- $\beta$ (TGF- $\beta$ ), interleukin-35 and interleukin- 6 which are secreted by macrophages, activation of the WNT signaling pathway and platelet-derived growth factor, and exposure to nicotine, alcohol and ultraviolet light also exacerbate this process (12-17). Epidermal growth factor (EGF) and hepatocyte growth factor, which are secreted by monocytes and neutrophils, and the presence of inflammation are also strong predisposing factors for EMT (18). Additionally, Twist, SNAIL, Zeb and other genes have also been shown to serve a crucial regulatory role in EMT (19-21). As tumor cells undergo EMT, the number of intercellular junctions reduce 
notably, as well as the expression of epithelial markers, such as keratin, E-cadherin and epithelial cell adhesion molecule (Ep-CAM) (22). Conversely, expression of mesenchymal markers such as vimentin are increased, and subsequently the morphology of the cells are altered allowing for detachment from the primary tumor, and ultimately becoming invasive $(14,23)$. Centrosome amplification and CTC clusters are also hypothesized to confer invasive and metastatic properties to tumor cells $(24,25)$.

Once cells detach from the primary tumor, the tumor cells near the neovascular site enter blood vessels through the sparse vascular endothelium under increased pressure of tumor tissue growth which facilitates extrusion (26). Additionally, changes in the extracellular matrix increase the synthesis of key components such as collagen and fibronectin, and simultaneously promote the development of abnormal structures in the extracellular matrix, through increased activity of members of the cathepsin and matrix metalloproteinases families of proteins, which are secreted by neutrophils and mast cells $(27,28)$. Macrophages and inflammatory monocytes enhance the migration of tumor cells by increasing the synthesis and cross-linking of collagen and fibronectin $(29,30)$. Natural killer cells reduce the expression of fibronectin by secreting interferon- $\gamma$, thereby limiting the migration of tumor cells (31). These changes all contribute to the breakdown of the extracellular matrix and intravasation of tumor cells into blood vessels. Subsequently, tumor cells use chemotaxis to migrate to sites of high vascular permeability to intravasate (Fig. 1A), and macrophages serve an essential role in this process. Macrophages alter vascular structures and increase permeability by secreting a series of growth factors such as the vascular endothelial growth factor (VEGF), fibroblast growth factor, and placenta-derived growth factor, which facilitate migration of tumor cells through the vascular endothelium $(32,33)$. Additionally, macrophages recruit tumor cells via the epidermal growth factor (EGF) paracrine loop to sites where vascular permeability is higher and thus more readily penetrable (34). This paracrine loop is regulated by the secretion of colony-stimulating factor (CSF-1) from tumor cells. CSF-1 regulates macrophages, increasing the production of EGF, and these macrophages are recruited to blood vessels, forming a chemical concentration gradient of EGF to guide the tumor cells towards the blood vessels $(35,36)$. This macrophage-mediated chemotaxis can be antagonized by $\mathrm{T}$ cells (37).

CTCs survive in the bloodstream and extravasate from the blood vessels at specific locations. CTCs in the blood face three challenges to survive, blood flow shear, anoikis, and immune cell identification and killing (38). Blood flow shear force is a double-edged sword. Under certain conditions, blood flow shear can increase the invasive and metastatic capacity of CTCs by activating yes-associated protein 1, as well as the ability to adhere to and penetrate blood vessels (39). Conversely, CTCs can be physically destroyed by blood flow shear (40), and the longer CTCs are present in the blood circulation, the lower their proliferative capacity becomes, and eventually the cells enter dormancy (41). Tumor cells undergoing EMT exhibit an improved ability to resist the blood flow shear force (42). When the tumor cells detach from their original microenvironment, the original extracellular matrix is unable to provide the necessary cytokines and signals for growth and survival resulting in death. This programmed death of the tumor cells is called anoikis. In CTCs, activation of the Akt pathway triggers tropomyosin-related kinase B and inhibits caspase-related apoptosis to counter anoikis (43). Furthermore, the Akt signaling pathway is activated in tumor cells and resists apoptosis induced by tumor necrosis factor-related apoptosis-inducing ligand, and this is mediated by vascular cell adhesion factor-1 (VCAM-1) (44). Platelets serve a crucial role in the resistance of CTCs to immune cell-mediated killing (Fig. 1B). Platelets can adhere to CTCs, forming an armor to resist blood flow shear (45), and natural killer (NK) cells recognize and kill the CTCs $(46,47)$. However, platelets induce EMT in CTCs via the NF- $\kappa \mathrm{B}$ and TGF- $\beta$ signaling pathways (48), and as mentioned earlier, CTCs which have undergone EMT are more resistant to blood flow shear (42). Platelets may also prevent CTCs from NK cell recognition by transferring major histocompatibility complex 1 molecules to CTCs and secreting TGF- $\beta$ to decrease the expression of NK cell NK Group 2D (49,50). Furthermore, platelets act as a link between $\mathrm{CTCs}$ and $\mathrm{CD} 11^{+}$macrophages to form cell clusters which help CTCs survive in the bloodstream (51). Additionally, CTCs selectively express Programmed death-ligand 1 (PD-L1), CD47 and Fas/Fasl which reduce the elimination of CTCs by immune cells (52-55).

Extravasation of CTCs from blood vessels is associated with several factors, such as the vascular endothelium linkage state, blood circulation state, capillary structure and adhesion of CTCs to the vessel wall (56-59). When CTCs pass through the capillaries, the flow rate decreases and CTCs adhere to the vascular endothelium with the assistance of platelets and neutrophils $(60,61)$. Mononuclear macrophages are recruited to the vascular endothelium, and CTCs adhere through C-C Motif Chemokine Ligand 2, and subsequently secrete VEGF, increasing the permeability of vascular endothelium and thus assisting extravasation of CTCs $(62,63)$.

Dormancy and activation of tumor cells. CTCs do not immediately contribute to metastasis, but remain dormant possibly for several years following extravasation and colonization of a distant site (Fig. 1B) (64). However, the processes underlying the ability of tumor cells to survive and enter a dormant state are complex. Myeloid cells, monocytes and macrophages, including neutrophils and the factors secreted by these cells accumulate at the metastatic site, producing an inhibitory environment for immune responses, thus assisting the tumor cells entry into dormancy prior to the arrival of tumor cells at the dissemination site $(34,65,66)$. Additionally, tumor cells resist apoptosis through activation of the Akt signaling pathway and thus improving tumor viability $(4,44,67)$. Tumor cells enter dormancy and are divided into three stages, angiogenesis dormancy, immune dormancy and tumor cell dormancy (64). Tumor growth requires a large number of new blood vessels to ensure a sufficient supply of nutrients $(68,69)$. During the dormant phase, angiogenesis is not activated (64). Proliferating tumor cells are in equilibrium with tumor cells that die due to a lack of oxygen and other nutrients due to the angiogenesis dormancy $(68,70)$. In terms of immune dormancy, it has been confirmed in animal models that the presence of lymphocytes, particularly $\mathrm{CD}^{+}$ $\mathrm{T}$ cells, can maintain tumor dormancy and reduce metastasis (71). The deletion of $\mathrm{CD}^{+} \mathrm{T}$ cells results in a $100 \%$ tumor 


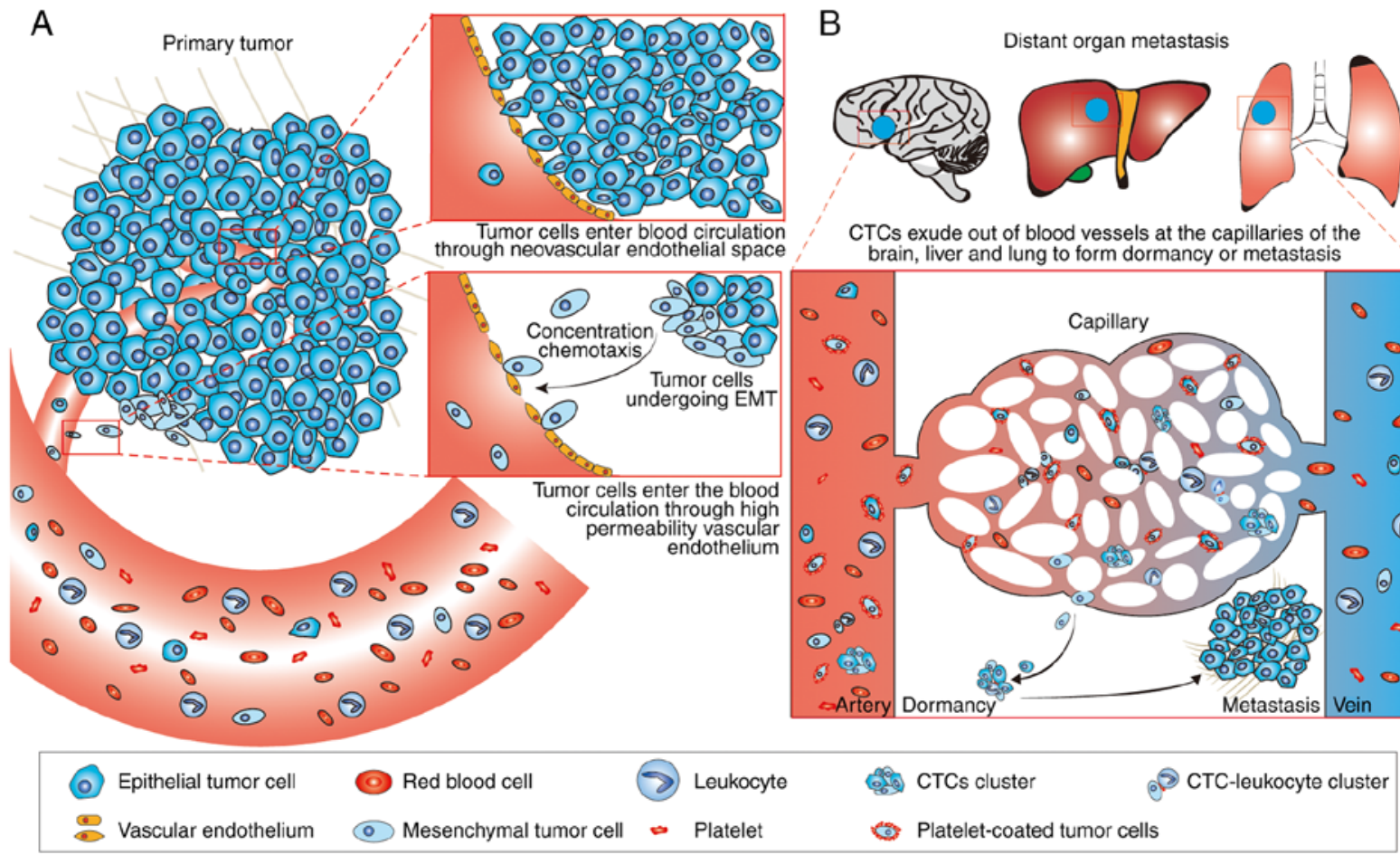

Figure 1. Biology of CTCs. (A) Tumor cells enter blood circulation through gaps between neovascular endothelial cells or vessels with greater permeability. CTCs counteract blood flow shear, anoikis and resist immune-mediated killing during circulation. (B) When CTCs flow through the capillaries of the distal organs, they eventually extravasate and enter dormancy. Under certain conditions, tumor cells exit this dormant state to form a metastasis. CTC, circulating tumor cell; EMT, epithelial-mesenchymal transition.

metastasis rate (72). In addition, EMT in tumor cells (26), and disruption of the balance between extracellular signal-regulated kinases and p38 mitogen-activated protein kinases (73), alters the expression of urokinase plasminogen activator receptor and integrin- $\beta 1$ (74), activation of TGF- $\beta 2$ signaling pathway (75) and expression changes in Myc gene (64), which all regulate the entry of tumor cells into a dormant state. When tumor cells enter dormancy, immune cells and conventional cytotoxic chemotherapy does not kill these cells; in conditions of post-operative stress, such as ischemia-reperfusion, sympathetic excitation, inflammation and hypercoagulability, these dormant cells may be activated, resulting in recurrence and metastasis in patients who underwent primary tumor resection $(34,76)$. Exit from dormancy is also a complicated process. Tumor cells exit dormancy and gain proliferative capacity, when they undergo mesenchymal-epithelial transition (26), and this process involves tumor necrosis factor- $\alpha$, interleukin-6 (77), integrin, activation of the Fak signaling pathway (78) and prostaglandin E2 (79). TGF- $\beta$ receptor antagonists awaken tumor cells from dormancy by blocking the bone morphogenetic protein signaling pathway and thus improving tumor stem cell characteristics (80).

\section{Isolation and detection of CTCs}

In general, there are 1-10 CTCs per 1 billion blood cells, and these extremely rare CTCs are heterogeneous (81). This combined heterogeneity and rarity poses a great challenge for separating and detecting CTCs, as separation and detection technologies must exhibit specificity, repeatability and in particular sensitivity $(2,82)$. At present, there are various CTC detection and separation techniques which can be crudely divided into two categories (Fig. 2A). The first method relies on specific markers on the surface of CTCs to separate them using antibody capture $(83,84)$. The second method relies on the physical properties of CTCs, such as size, density, and electrophysiological characteristics $(2,85)$. In addition, certain more recent techniques have combined the use of antibody capture with separation based on physical properties, such as preliminary isolation by size of CTCs, and further screening of CTCs using Ep-CAM antibody capture (86). Downstream DNA, RNA and protein levels can be analyzed to confirm that the captured cells are indeed CTCs (8).

The CellSearch system is the only technology approved by the US Food and Drug Administration (FDA) for capture of CTCs, and is a cell-specific marker antibody capture and separation technology. This system uses Ep-CAM antibody-coated immunomagnetic beads for capture of CTCs, similar to AdnaTest $(87,88)$ and IsoFlux (89). In addition to coating of magnetic beads with an Ep-CAM antibody, it is also coated on a microfluidic chip microcolumn (90), herringbone lumen (91) or wavy herringbone lumen (92), and the inner wall of the microfluidic chip. After the blood sample has passed through, CTCs are captured and retained on these devices for additional verification. Furthermore, the Ep-CAM antibody is coated on a functionalized medical line (CellCollector) (93), and the antibody-coated line is left in a patients vein for $30 \mathrm{~min}$ to obtain CTCs from the body, which are verified following isolation. Flow cytometry can isolate CTCs from the blood samples using fluorescein-labeled Ep-CAM antibodies (94). However, this method has certain limitations as not all CTCs express Ep-CAM (83). As mentioned above, most of the tumor cells undergo EMT, which results in the downregulation of 
A CTC separation method Separation of CTC by antibody
capture
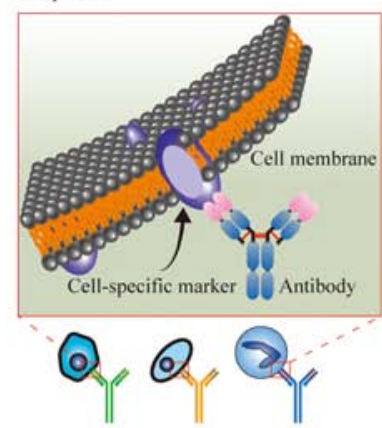

Separation of CTC by physical properties
Separation of CTC by combining antibody capture and physical properties

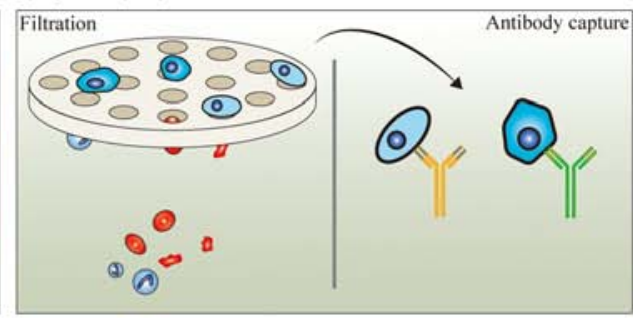

Epithelial tumor cell

Leukocyte $\quad$ Platelet

Mesenchymal tumor cell

Red blood cell

\section{B CTC detection method}
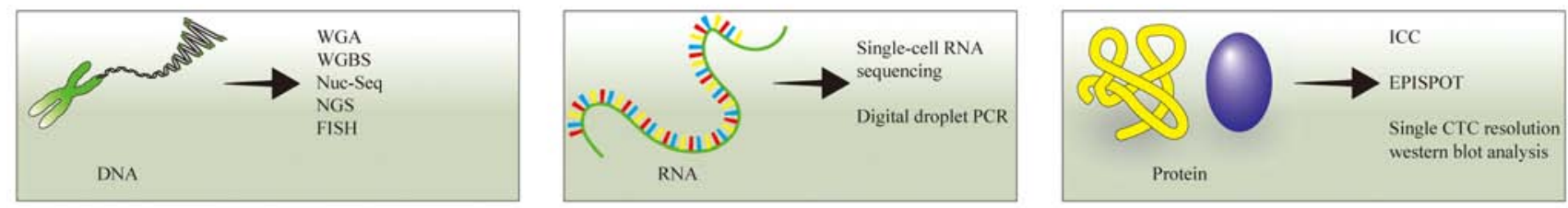

Figure 2. CTC separation and detection methods. (A) Separation methods of CTCs are divided into two types, antibody capture and physical capture. In antibody capture, the most commonly used antibody is Ep-CAM; Vimentin and leukocyte antibody CD45 are used for negative isolation. Physical capture primarily uses the difference in size and density of cells to separate CTC by filtration or centrifugation. One method combines both antibody capture with physical capture. (B) CTCs can be identified and analyzed based on DNA, RNA and protein expression, after obtaining CTCs. FISH, WGA are commonly used for DNA analysis, single-cell RNA sequencing is commonly used for RNA analysis, and ICC is commonly used for protein expression analysis. CTC, circulating tumor cell; Ep-CAM, epithelial cell adhesion molecule; FISH, fluorescence in situ hybridization; WGA, whole-genome amplification; ICC, immunocytochemistry; WGBS, whole-genome bisulfite sequencing; Nuc-Seq, whole-genome and exome single cell sequencing approach; NGS, next generation sequencing; EPISPOT, epithelial immunospot.

cell-surface epithelial markers such as Ep-CAM and keratin, and simultaneously, expression of mesenchymal markers, such as vimentin, are increased (12). This results in only $80 \%$ of solid tumors expressing Ep-CAM (95). Therefore, other types of antibodies have been adapted for capture of non-epithelial CTCs, such as the mesenchymal antibodies N-cadherin (96), Vimentin (97), and stem cell-specific antibodies CD44 (98). Heterogeneity of CTCs leads to inefficient capture of CTCs in different patients, and even in the same patient when only one antibody is used (82). Therefore, a negative screening technique was introduced. By enriching and discarding white blood cells expressing CD45, the remaining cells were identified to be CTCs, expressing different markers using tools such as Diagnostic Leuk Apheresis (99) and RosetteSep (100).

In addition to capturing CTCs using antibodies, it is possible to isolate CTCs based on their physical properties. Systems to isolate CTCs from blood cells based on size include ISET (101), CanPatrol (102), ScreenCell (103), Parsortix (104), CelSee (105) and microcavity array system (106). However, this method has certain drawbacks as not all CTCs are larger than white blood cells (90). Using the differences in density between CTCs and blood cell, CTCs can be obtained by centrifugation, for example by using Ficoll density gradient separation (107) and OncoQuick (108). Other techniques for capturing CTCs include separation based on electrophysiological features, such as dielectrophoretic field-flow fractionation (109) and dielectrophoretic array platform (110). In addition to the above separation methods, there are several novel detection methods, such as the multifunctional Branched Nanostraw-electroporation platform (111), which can capture CTCs, and also puncture the cell membrane without damaging the cell to assess the intracellular environment and transport drug molecules into the CTCs. Optofluidic flow cytometer can be used for consecutive CTC separation, 3D focusing and single-cell phenotypic counting (112). The Cytophone platform uses an in vivo photoacoustic flow cytometry platform with a high pulse rate laser and focused ultrasound transducers for label-free detection of CTCs (113). Furthermore, there are separation methods that combine antibody capture with physical properties, such as CTC-iCHIP (86) and 3D-printed microfluidic devices (114), which capture CTCs more efficiently by combining antibody beads with CTC size filtration.

CTC detection technology. After CTCs have been isolated using one of the above methods, confirmation of their identity needs to be verified, and a series of tests are performed to assess the cells and obtain information regarding the original tumor information from which the CTCs were derived (Fig. 2B). Immunocytochemistry is used to determine the expression of specific markers, thereby defining the identity of the CTCs. For example, in CellSearch, cells $\geq 4 \mu \mathrm{m}, 4$,6-diamino-2-phenylindole $\left(\mathrm{DAPI}^{+}\right)$, keratin ${ }^{+}$and $\mathrm{CD} 45^{-}$are used as criteria for determining CTCs (115), and the expression of molecules on the surface of CTCs may also be analyzed by this technique, such as by staining for EMT-associated molecules (116). The classification of CTCs may also be confirmed using a 4-color fluorescence detection system (112). If cells are isolated and cultured, the proteins secreted by the cells can be detected using EPISPOT, to determine the identity of the CTCs (117). PCR can also be used for the identification of CTCs and for profiling the transcript of tumors, EMT, stem cell characteristics such as Ep-CAM, aldehyde dehydroge- 
A CTCs related cell and animal experiment

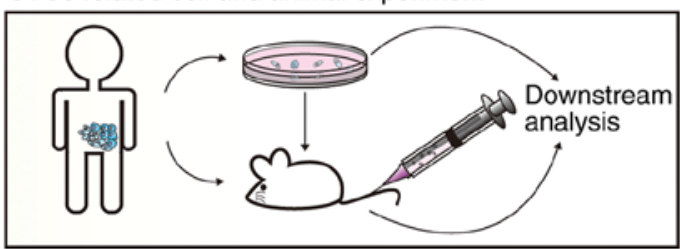

B CTC related clinical research

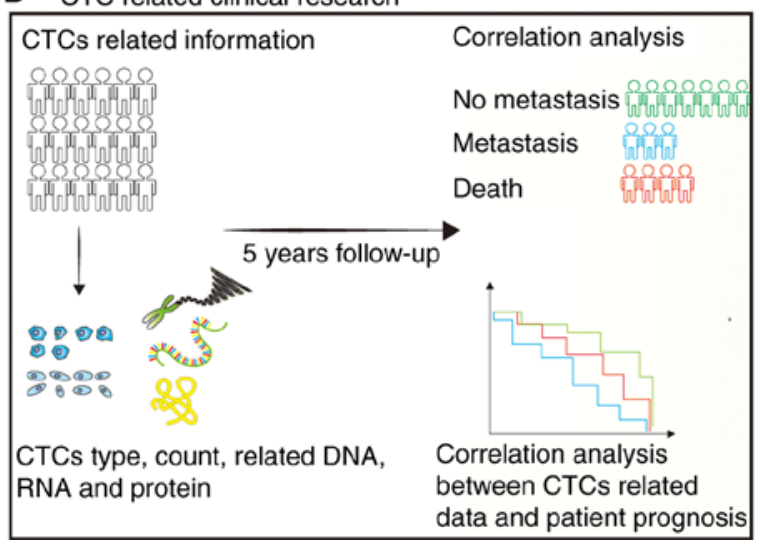

Figure 3. CTC associated research methods. (A) CTC associated cell and animal methods. A large number of CTCs are obtained from patients with high CTC counts, which are directly injected into nude mice for in vivo analysis, or cultured into cell lines for in vivo or in vitro studies. (B) Clinical trials of CTCs. The value of CTCs for prognosis was tested by combining CTC-associated detection and patient follow-up data.

nase 1 and Twist1 (118). With the emergence of whole-genome amplification (119), whole-genome bisulfite sequencing (120), whole-genome and exome single-cell sequencing (121), next-generation sequencing (117), third-generation sequencing (120) and low-pass whole genome and targeted next-generation sequencing (121), our understanding of CTC gene mutations has increased notably. In addition to the single-cell level, the association between the CTC phenotype and gene mutations can be visualized using fluorescence in situ hybridization (FISH) (122), without the need to separate individual cells by micromanipulation following CTC enrichment. For RNA, the emergence of technologies such as single-cell RNA sequencing (8) and digital droplet PCR (123), have allowed for a deeper understanding of the biological changes of CTCs at the transcriptional level. Furthermore, other novel technologies allow for assessment of the changes in protein expression levels from an individual CTC. For example, single CTC resolution western blot analysis can quantify 12 proteins simultaneously, this technology, when combined with flow cytometry, can quantify $>40$ proteins, significantly improving screening efficiency $(124,125)$. Fluctuations in $\mathrm{pH}$ or detection of lactate concentrations have been employed in a microfluidic device to identify the metabolic status of CTCs (126).

\section{CTC associated research methods}

Research on CTCs can be divided into two categories, research at the cell and animal level, and clinical research focusing on the clinical prognosis of patients. Examination of phenotypes, characteristics, gene mutation sites and drug susceptibility of CTCs are primarily studied by culturing CTCs-associated cell lines and using cell biology and molecular biology techniques, and subsequently verified using in vivo experiments (127-129). In clinical trials, evaluation is performed by combining the number, type, and protein expression profiles of CTCs in patients' blood with clinical prognosis and personalized treatment $(123,130)$. At present, the primary clinical value of CTCs includes the assessment of disease-free survival and overall survival prognosis (131), surveillance of minimal residual lesions, recurrence and metastasis $(8,132)$, and to personalize treatment and determine the effects of the treatment $(133,134)$.

Cell and animal research. Due to the rarity of CTCs, and the difficulty in isolating CTCs whilst simultaneously maintaining their survival outside of the body, certain studies are performed at the cellular or animal level compared with clinical studies of CTCs. In the case of patients with relatively high concentrations of CTCs, cell and animal research of their CTCs is possible (Fig. 3A). In a patient with colorectal cancer, the CTC concentration was $>300 / 7.5 \mathrm{ml}$, thus blood was enriched and cultured, and a cell line based on their CTCs was successfully obtained (127). Studies on gene transcription, protein expression and secretion levels demonstrated that CTCs have primitive tumor cell and stem cell characteristics, mixed epithelial and mesenchymal phenotypes, and strong tumorigenic ability in animal experiments. In breast cancer, CTCs obtained from patients have mutations in the gene of PIK3CA, estrogen receptor 1 , fibroblast growth factor receptor 2, and drug sensitivity to the mutations (128). Another study showed that CTCs with human epidermal growth factor receptor 2/epidermal growth factor receptor/Heparanase/Notch $1^{+}$ have a tendency to metastasize to the brain in animal experiments (129). Similar studies have also been performed in prostate cancer (135), non-small cell lung cancer (136), and small cell lung cancer $(137,138)$, and the tumorigenicity, drug resistance, and mutation sites of CTCs having been confirmed. Through these studies, a more comprehensive understanding of the relationship between CTCs and the metastatic tendency of different organs can be determined (139), and this individualized treatment (128) and the mechanisms underlying increased invasion and metastasis may be elucidated (140).

Clinical research. In clinical studies, research can be broadly divided into two categories, bivariate studies, and multivariate studies. In bivariate studies, the two variables are CTC-related data and patient clinical follow-up data (Fig. 3B). CTC-related data includes the number of CTCs, and protein, DNA and RNA expression profiles. Patient follow-up data primarily include disease-free survival, overall survival, chemotherapy medication and methods, and recurrence. CTCs are used as a predictor of clinical prognosis, chemoresistance, and for detection of tumor metastasis and recurrence. For example, in advanced pancreatic ductal adenocarcinoma, the number of CTCs is an important predictor of disease-free survival and overall survival prior to, and following first-line chemotherapy; the higher the number of CTCs, the shorter the disease-free survival and overall survival of patients (123). However, the mRNA expression levels of activated leukocyte cell adhesion molecule, POU Class 5 Homeobox 1B and smoothened are increased in CTCs, and this is associated with less favorable overall and disease-free survival (123). In metastatic 
castration-resistant prostate cancer patients, patients with CTCs expressing nuclear localization androgen receptor splice variant 7 (ARV7) exhibit improved responses to taxanes and androgen receptor inhibitors; conversely androgen receptor inhibitors result in improved outcomes compared with taxanes in patients whose CTCs do not express nuclear localization of ARV7 (133). In breast cancer, CTCs expressing Notch signaling pathway markers are closely associated with brain metastasis (132). Related bivariate studies have also been performed on non-small cell lung cancer (131), colorectal cancer (141), liver cancer (130) and kidney cancer (116). However, studies on hepatic carcinoma have rarely yielded a negative result, counts of CTCs and types of EMT are not associated with clinical stage and predictive recurrence of hepatic carcinoma (130). In addition, CTCs and solid tumor DNA (142) or protein analysis (143) were used as two elements for correlation analysis to compare the variation of primary tumors and CTCs. However, in patients with lung cancer, there was no correlation between PD-L1 on CTCs and in tumor tissues (106).

In multivariate studies, in addition to the aforementioned CTC data and patient follow-up data, TNM staging (144) or other liquid biopsy markers, such as circulating tumor DNA (145) and extracellular vesicles (146), can be used together as predictors of prognosis to improve prediction accuracy. For example, in colorectal cancer, postoperative CTC counts are more valuable than preoperative counts, and TNM staging, and postoperative CA724 and CTCs counts are more accurate for predicting disease-free survival of patients, and there is a model to predict early recurrence and postoperative survival rate using postoperative CA724, CTCs counts, which can include or exclude TNM staging (141). As mentioned above, CTCs are closely associated with platelets and immune cells in the circulatory system; therefore, by combining CTC data, immune-inflammatory cell counts in circulating blood, coagulation status and other factors with patient follow-up data, the accuracy of predicting prognosis and assessing risk can be improved. In metastatic breast cancer, the ratio of CTCs to blood inflammatory cells, such as the ratio of CTCs to monocytes and lymphocytes, can be used as a predictor of prognosis (147). Also in metastatic breast cancer, by combining CTC data with thrombin-anti-thrombin III, fibrinogen, D-dimer and patient follow-up data, it has been shown that the hypercoagulable state contributes to tumor cell metastasis (148).

\section{Conclusion}

Tumor metastasis and recurrence is a major cause of cancer-associated death, and CTCs serve an important role in this process. During tumor cell detachment from solid tumors, cells enter the blood stream form distant metastases, and acquire an invasive phenotype, resisting the killing effect of the immune-inflammatory cells through EMT and various other mechanisms. During these complex and varied mechanisms, CTCs become heterogenous and unique. Therefore, the requirements for accurate separation and isolation of CTCs should be stringent. Traditional antibody capture technologies serve as the standard operating procedure, and these methods are relatively simple. Emerging capture technologies have greater sensitivities and specificities by combining antibody capture with CTC physics. However, these methods are time-consuming and expensive. Thus, developing a method that is simple, has a high capture rate and is accurate is required. Initially, CTCs were primarily used to predict the prognosis of patients based on their counts. CTC research is now focused on the molecular characteristics and the functions of the various molecular features of CTCs. With the use of CTC animal experiments, our understanding of biological behavior and mechanisms of CTCs has improved vastly and the development of tumor progression surveillance, prognosis assessment and individualized treatment has improved as a result.

In conclusion, CTCs possess value for prognosis assessment, metastasis surveillance and personalized treatment. They may be used to assess the presence of tumor metastases and recurrence, thus improving the prognosis of cancer patients, and reduce tumor-related mortality.

\section{Acknowledgements}

Not applicable.

\section{Funding}

Not applicable.

\section{Availability of data and materials}

The datasets used and/or analyzed during the present study are available from the corresponding author on reasonable request.

\section{Authors' contributions}

CT designed the study and revised the article. YBC, FSX, JHT collected and accessed relevant literature. CCY, SLH, HWC organized the content and structure of the literature. $\mathrm{KG}$, ZYW, MXH, MRL corrected the content of the article and produced the figures. All authors read and approved the final version of the manuscript.

\section{Ethical approval and consent to participate}

Not applicable.

\section{Patient consent for publication}

Not applicable.

\section{Competing interest}

The authors declare that they have no competing interests.

\section{References}

1. Lambert AW, Pattabiraman DR and Weinberg RA: Emerging biological principles of metastasis. Cell 168: 670-691, 2017.

2. Tayoun T, Faugeroux V, Oulhen M, Aberlenc A, Pawlikowska P and Farace F: CTC-derived models: A Window into the seeding capacity of circulating tumor cells (CTCs). Cells 8: pii: E1145, 2019. 
3. Obenauf AC and Massague J: Surviving at a distance: Organ-specific metastasis. Trends Cancer 1: 76-91, 2015.

4. Kang Y and Pantel K: Tumor cell dissemination: Emerging biological insights from animal models and cancer patients. Cancer Cell 23: 573-581, 2013

5. Rossi E and Fabbri F: CTCs 2020: Great expectations or unreasonable dreams. Cells 8: pii: E989, 2019.

6. Chaffer CL and Weinberg RA: A perspective on cancer cell metastasis. Science 331: 1559-1564, 2011.

7. Giuliano AE, Connolly JL, Edge SB, Mittendorf EA, Rugo HS Solin LJ, Weaver DL, Winchester DJ and Hortobagyi GN: Breast Cancer-Major changes in the American Joint Committee on Cancer eighth edition cancer staging manual. CA Cancer J Clin 67: 290-303, 2017.

8. Keller L and Pantel K: Unravelling tumour heterogeneity by single-cell profiling of circulating tumour cells. Nat Rev Cancer 19: 553-567, 2019.

9. Kessenbrock K, Plaks V and Werb Z: Matrix metalloproteinases: Regulators of the tumor microenvironment. Cell 141: 52-67, 2010

10. Quail DF and Joyce JA: Microenvironmental regulation of tumor progression and metastasis. Nat Med 19: 1423-1437, 2013.

11. Nieto MA: The ins and outs of the epithelial to mesenchymal transition in health and disease. Annu Rev Cell Dev Biol 27: 347-376, 2011.

12. Thiery JP, Acloque H, Huang RY and Nieto MA Epithelial-mesenchymal transitions in development and disease. Cell 139: 871-890, 2009.

13. Kishi S, Bayliss PE and Hanai J: A prospective epigenetic paradigm between cellular senescence and epithelial-mesenchymal transition in organismal development and aging. Trans Res 165: 241-249, 2015.

14. Dongre A and Weinberg RA: New insights into the mechanisms of epithelial-mesenchymal transition and implications for cancer. Nat Rev Mol Cell Biol 20: 69-84, 2019.

15. Tam WL and Weinberg RA: The epigenetics of epithelial-mesenchymal plasticity in cancer. Nat Med 19: 1438-1449, 2013

16. Lee CC, Lin JC, Hwang WL, Kuo YJ, Chen HK, Tai SK, Lin CC and Yang MH: Macrophage-secreted interleukin-35 regulates cancer cell plasticity to facilitate metastatic colonization. Nat Commun 9: 3763, 2018.

17. Linde N, Casanova-Acebes M, Sosa MS, Mortha A, Rahman A, Farias E, Harper K, Tardio E, Reyes Torres I, Jones J, et al: Macrophages orchestrate breast cancer early dissemination and metastasis. Nat Commun 9: 21, 2018.

18. Rhim AD, MirekET, Aiello NM, Maitr A,Bailey JM,McAllisterF Reichert M, Beatty GL, Rustgi AK, Vonderheide RH, et al: EMT and dissemination precede pancreatic tumor formation. Cell 148 349-361, 2012

19. Eckert MA,Lwin TM,Chang AT,Kim J,Danis E, Ohno-MachadoL and Yang J: Twist1-induced invadopodia formation promotes tumor metastasis. Cancer Cell 19: 372-386, 2011.

20. Guo W, Keckesova Z, Donaher JL, Shibue T, Tischler V, Reinhardt F, Itzkovitz S, Noske A, Zürrer-Härdi U, Bell G, et al: Slug and Sox 9 cooperatively determine the mammary stem cell state. Cell 148: 1015-1028, 2012

21. Wellner U, Schubert J, Burk UC, Schmalhofer O, Zhu F, Sonntag A, Waldvogel B, Vannier C, Darling D, zur Hausen A, et al: The EMT-activator ZEB1 promotes tumorigenicity by repressing stemness-inhibiting microRNAs. Nat Cell Biol 11: 1487-1495, 2009.

22. Polyak K and Weinberg RA: Transitions between epithelial and mesenchymal states: Acquisition of malignant and stem cell traits. Nat Rev Cancer 9: 265-273, 2009.

23. Joosse SA, Hannemann J, Spötter J, Bauche A, Andreas A, Müller V and Pantel K: Changes in keratin expression during metastatic progression of breast cancer: Impact on the detection of circulating tumor cells. Clin Cancer Res 18: 993-1003, 2012.

24. Godinho SA, Picone R, Burute M, Dagher R, Su Y, Leung CT, Polyak K, Brugge JS, Théry M and Pellman D: Oncogene-like induction of cellular invasion from centrosome amplification. Nature 510: 167-171, 2014.

25. Aceto N, Bardia A, Miyamoto DT, Donaldson MC, Wittner BS Spencer JA, Yu M, Pely A, Engstrom A, Zhu H, et al: Circulating tumor cell clusters are oligoclonal precursors of breast cancer metastasis. Cell 158: 1110-1122, 2014.

26. Joosse SA, Gorges TM and Pantel K: Biology, detection, and clinical implications of circulating tumor cells. EMBO Mo Med 7: 1-11, 2015.

27. Bonnans C, Chou J and Werb Z: Remodelling the extracellular matrix in development and disease. Nat Rev Mol Cell Biol 15: $786-801,2014$
28. Northey JJ, Przybyla L and Weaver VM: Tissue force programs cell fate and tumor aggression. Cancer Discov 7: 1224-1237, 2017

29. Sangaletti S, Di Carlo E, Gariboldi S, Miotti S, Cappetti B, Parenza M, Rumio C, Brekken RA, Chiodoni C and Colombo MP: Macrophage-derived SPARC bridges tumor cell-extracellular matrix interactions toward metastasis. Cancer Res 68: 9050-9059, 2008

30. Porrello A, Leslie PL, Harrison EB, Gorentla BK, Kattula S, Ghosh SK, Azam SH, Holtzhausen A, Chao YL, Hayward MC, et al: Factor XIIIA-expressing inflammatory monocytes promote lung squamous cancer through fibrin cross-linking. Nat Commun 9: 1988, 2018.

31. Glasner A, Ghadially H, Gur C, Stanietsky N, Tsukerman P, Enk $\mathrm{J}$ and Mandelboim O: Recognition and prevention of tumor metastasis by the NK receptor NKp46/NCR1. J Immunol 188: 2509-2515, 2012.

32. Rivera LB and Bergers G: Intertwined regulation of angiogenesis and immunity by myeloid cells. Trends Immunol 36: 240-249, 2015.

33. Harney AS, Arwert EN, Entenberg D, Wang Y, Guo P, Qian BZ, Oktay MH, Pollard JW, Jones JG and Condeelis JS: Real-time imaging reveals local, transient vascular permeability, and tumor cell intravasation stimulated by TIE2hi macrophage-derived VEGFA. Cancer Discov 5: 932-943, 2015

34. El-Kenawi A, Hanggi K and Ruffell B: The immune microenvironment and cancer metastasis. Cold Spring Harb Perspect Med: pii: a037424, 2019 (Epub ahead of print).

35. Arwert EN, Harney AS, Entenberg D, Wang Y, Sahai E, Pollard JW and Condeelis JS: A Unidirectional transition from migratory to perivascular macrophage is required for tumor cell intravasation. Cell Rep 23: 1239-1248, 2018.

36. Ishihara D, Dovas A, Hernandez L, Pozzuto M, Wyckoff J, Segall JE, Condeelis JS, Bresnick AR and Cox D: Wiskott-Aldrich syndrome protein regulates leukocyte-dependent breast cancer metastasis. Cell Rep 4: 429-436, 2013.

37. DeNardo DG, Barreto JB, Andreu P, Vasquez L, Tawfik D, Kolhatkar N and Coussens LM: CD4(+) T cells regulate pulmonary metastasis of mammary carcinomas by enhancing protumor properties of macrophages. Cancer Cell 16: 91-102, 2009.

38. Mohme M, Riethdorf S and Pantel K: Circulating and disseminated tumour cells-mechanisms of immune surveillance and escape. Nat Rev Clin Oncol 14: 155-167, 2017.

39. Tsukamoto K and Niikawa N: Gene responsible for Waardenburg syndrome type I. Tanpakushitsu Kakusan Koso 38: 361-365, 1993 (In Japanese).

40. Labelle M and Hynes RO: The initial hours of metastasis: The importance of cooperative host-tumor cell interactions during hematogenous dissemination. Cancer Discov 2: 1091-1099, 2012.

41. Fan R, Emery T, Zhang Y, Xia Y, Sun J and Wan J: Circulatory shear flow alters the viability and proliferation of circulating colon cancer cells. Sci Rep 6: 27073, 2016.

42. Mitchell MJ and King MR: Computational and experimental models of cancer cell response to fluid shear stress. Front Oncol 3: 44, 2013.

43. Douma S, Van Laar T, Zevenhoven J, Meuwissen R, Van Garderen E and Peeper DS: Suppression of anoikis and induction of metastasis by the neurotrophic receptor TrkB. Nature 430: 1034-1039, 2004

44. Chen Q, Zhang XH and Massague J: Macrophage binding to receptor VCAM-1 transmits survival signals in breast cancer cells that invade the lungs. Cancer Cell 20: 538-549, 2011

45. Leblanc R and Peyruchaud O: Metastasis: New functional implications of platelets and megakaryocytes. Blood 128: 24-31, 2016.

46. Seth R, Tai LH, Falls T, de Souza CT, Bell JC, Carrier M, Atkins H, Boushey R and Auer RA: Surgical stress promotes the development of cancer metastases by a coagulation-dependent mechanism involving natural killer cells in a murine model. Ann Surg 258: 158-168, 2013.

47. Palumbo JS, Talmage KE, Massari JV, La Jeunesse CM, Flick MJ, Kombrinck KW, Jirousková M and Degen JL: Platelets and fibrin(ogen) increase metastatic potential by impeding natural killer cell-mediated elimination of tumor cells. Blood 105: $178-185,2005$

48. Labelle M, Begum S and Hynes RO: Direct signaling between platelets and cancer cells induces an epithelial-mesenchymal-like transition and promotes metastasis. Cancer Cell 20: 576-590, 2011. 
49. Placke T, Orgel M, Schaller M, Jung G, Rammensee HG, Kopp HG and Salih HR: Platelet-derived MHC class I confers a pseudonormal phenotype to cancer cells that subverts the antitumor reactivity of natural killer immune cells. Cancer Res 72: 440-448, 2012.

50. Kopp HG, Placke T and Salih HR: Platelet-derived transforming growth factor-beta down-regulates NKG2D thereby inhibiting natural killer cell antitumor reactivity. Cancer Res 69: 7775-7783, 2009.

51. Gil-Bernabe AM, Ferjancic S, Tlalka M, Zhao L, Allen PD Im JH, Watson K, Hill SA, Amirkhosravi A, Francis JL, et al: Recruitment of monocytes/macrophages by tissue factor-mediated coagulation is essential for metastatic cell survival and premetastatic niche establishment in mice. Blood 119: 3164-3175, 2012

52. Yue C, Jiang Y, Li P, Wang Y, Xue J, Li N, Li D, Wang R, Dang Y, $\mathrm{Hu} \mathrm{Z}$, et al: Dynamic change of PD-L1 expression on circulating tumor cells in advanced solid tumor patients undergoing PD-1 blockade therapy. Oncoimmunology 7: e1438111, 2018.

53. Kallergi G, Vetsika EK, Aggouraki D, Lagoudaki E, Koutsopoulos A, Koinis F, Katsarlinos P, Trypaki M, Messaritakis I, Stournaras C, et al: Evaluation of PD-L1/PD-1 on circulating tumor cells in patients with advanced non-small cell lung cancer. Ther Adv Med Oncol 10: 1758834017750121, 2018.

54. Baccelli I, Schneeweiss A, Riethdorf S, Stenzinger A, Schillert A, Vogel V, Klein C, Saini M, Bäuerle T, Wallwiener M, et al: Identification of a population of blood circulating tumor cells from breast cancer patients that initiates metastasis in a xenograft assay. Nat Biotechnol 31: 539-544, 2013.

55. Hallermalm K, De Geer A, Kiessling R, Levitsky V and Levitskaya J: Autocrine secretion of Fas ligand shields tumor cells from Fas-mediated killing by cytotoxic lymphocytes. Cancer Res 64: 6775-6782, 2004.

56. Follain G, Osmani N, Azevedo AS, Allio G, Mercier L, Karreman MA, Solecki G, Garcia Leòn MJ, Lefebvre O, Fekonja N, et al: Hemodynamic forces tune the arrest, adhesion, and extravasation of circulating tumor cells. Dev Cell 45: 33-52 e12, 2018

57. Yano K, Gale D, Massberg S, Cheruvu PK, Monahan-Earley R, Morgan ES, Haig D, von Andrian UH, Dvorak AM and Aird WC: Phenotypic heterogeneity is an evolutionarily conserved feature of the endothelium. Blood 109: 613-615, 2007.

58. Yasmin-Karim S, King MR, Messing EM and Lee YF: E-selectin ligand-1 controls circulating prostate cancer cell rolling/adhesion and metastasis. Oncotarget 5: 12097-12110, 2014.

59. Tichet M, Prod'Homme V, Fenouille N, Ambrosetti D, Mallavialle A, Cerezo M, Ohanna M, Audebert S, Rocchi S, Giacchero D, et al: Tumour-derived SPARC drives vascular permeability and extravasation through endothelial VCAM1 signalling to promote metastasis. Nat Commun 6: 6993, 2015.

60. Gay LJ and Felding-Habermann B: Contribution of platelets to tumour metastasis. Nat Rev Cancer 11: 123-134, 2011.

61. Spicer JD, McDonald B, Cools-Lartigue JJ, Chow SC, Giannias B, Kubes P and Ferri LE: Neutrophils promote liver metastasis via Mac-1-mediated interactions with circulating tumor cells. Cancer Res 72: 3919-3927, 2012

62. Qian BZ, Li J, Zhang H, Kitamura T, Zhang J, Campion LR, Kaiser EA, Snyder LA and Pollard JW: CCL2 recruits inflammatory monocytes to facilitate breast-tumour metastasis. Nature 475: 222-225, 2011.

63. Reymond N, d'Agua BB and Ridley AJ: Crossing the endothelial barrier during metastasis. Nat Rev Cancer 13: 858-870, 2013.

64. Endo H and Inoue M: Dormancy in cancer. Cancer Sci 110: 474-480, 2019

65. Liu Y and Cao X: Characteristics and Significance of the Pre-metastatic Niche. Cancer Cell 30: 668-681, 2016.

66. Kaplan RN, Riba RD, Zacharoulis S, Bramley AH, Vincent L, Costa C, MacDonald DD, Jin DK, Shido K, Kerns SA, et al: VEGFR1-positive haematopoietic bone marrow progenitors initiate the pre-metastatic niche. Nature 438: 820-827, 2005.

67. Zhang XH, Wang Q, Gerald W, Hudis CA, Norton L, Smid M, Foekens JA and Massagué J: Latent bone metastasis in breast cancer tied to Src-dependent survival signals. Cancer Cell 16 67-78, 2009.

68. Hanahan D and Weinberg RA: Hallmarks of cancer: The next generation. Cell 144: 646-674, 2011.

69. Hanahan D and Weinberg RA: The hallmarks of cancer. Cell 100: $57-70,2000$.
70. Indraccolo S, Stievano L, Minuzzo S, Tosello V, Esposito G, Piovan E, Zamarchi R, Chieco-Bianchi L and Amadori A: Interruption of tumor dormancy by a transient angiogenic burst within the tumor microenvironment. Proc Natl Acad Sci USA 103: 4216-4221, 2006

71. Eyles J, Puaux AL, Wang X, Toh B, Prakash C, Hong M, Tan TG, Zheng L, Ong LC, Jin Y, et al: Tumor cells disseminate early, but immunosurveillance limits metastatic outgrowth, in a mouse model of melanoma. J Clin Invest 120: 2030-2039, 2010.

72. Romero I, Garrido C, Algarra I, Collado A, Garrido F and Garcia-Lora AM: T lymphocytes restrain spontaneous metastases in permanent dormancy. Cancer Res 74: 1958-1968, 2014.

73. Sosa MS, Avivar-Valderas A, Bragado P, Wen HC and Aguirre-Ghiso JA: ERK1/2 and $\mathrm{p} 38 \alpha / \beta$ signaling in tumor cell quiescence: Opportunities to control dormant residual disease. Clin Cancer Res 17: 5850-5857, 2011.

74. Aguirre-Ghiso JA: Models, mechanisms and clinical evidence for cancer dormancy. Nat Rev Cancer 7: 834-846, 2007.

75. Yumoto K, Eber MR, Wang J, Cackowski FC, Decker AM, Lee E, Nobre AR, Aguirre-Ghiso JA, Jung Y and Taichman RS: Axl is required for TGF- $\beta 2$-induced dormancy of prostate cancer cells in the bone marrow. Sci Rep 6: 36520, 2016.

76. Chen Z, Zhang P, Xu Y, Yan J, Liu Z, Lau WB, Lau B, Li Y, Zhao X, Wei Y and Zhou S: Surgical stress and cancer progression: The twisted tango. Mol Cancer 18: 132, 2019.

77. Ruffell B and Coussens LM: Macrophages and therapeutic resistance in cancer. Cancer Cell 27: 462-472, 2015.

78. Albrengues J, Shields MA, Ng D, Park CG, Ambrico A, Poindexter ME, Upadhyay P, Uyeminami DL, Pommier A, Küttner V, et al: Neutrophil extracellular traps produced during inflammation awaken dormant cancer cells in mice. Science 361: pii: eaao4227, 2018.

79. Sosnoski DM, Norgard RJ, Grove CD, Foster SJ and Mastro AM Dormancy and growth of metastatic breast cancer cells in a bone-like microenvironment. Clin Exp Metastasis 32: 335-344, 2015.

80. Gao H, Chakraborty G, Lee-Lim AP, Mo Q, Decker M, Vonica A, Shen R, Brogi E, Brivanlou AH and Giancotti FG: The BMP inhibitor Coco reactivates breast cancer cells at lung metastatic sites. Cell 150: 764-779, 2012.

81. Ting DT, Wittner BS, Ligorio M, Vincent Jordan N, Shah AM, Miyamoto DT, Aceto N, Bersani F, Brannigan BW, Xega K, et al: Single-cell RNA sequencing identifies extracellular matrix gene expression by pancreatic circulating tumor cells. Cell Rep 8: 1905-1918, 2014

82. Lee MW, Kim GH, Jeon HK and Park SJ: Clinical application of circulating tumor cells in gastric cancer. Gut Liver 13: 394-401, 2019.

83. Gorges TM, Tinhofer I, Drosch M, Röse L, Zollner TM, Krahn T and von Ahsen O: Circulating tumour cells escape from EpCAM-based detection due to epithelial-to-mesenchymal transition. BMC Cancer 12: 178, 2012.

84. Sen M, Wang L, Yu L and Carpenter EL: Rare event phenotyping and molecular characterization: Circulating tumor cells. Methods Mol Biol 2032: 213-226, 2019.

85. Kim TH, Lim M, Park J, Oh JM, Kim H, Jeong H, Lee SJ, Park HC, Jung S, Kim BC, et al: FAST: Size-selective, Clog-free isolation of rare cancer cells from whole blood at a liquid-liquid interface. Anal Chem 89: 1155-1162, 2017.

86. Ozkumur E, Shah AM, Ciciliano JC, Emmink BL, Miyamoto DT, Brachtel E, Yu M, Chen PI, Morgan B, Trautwein J, et al: Inertial focusing for tumor antigen-dependent and -independent sorting of rare circulating tumor cells. Sci Transl Med 5: 179ra147, 2013.

87. Danila DC, Samoila A, Patel C, Schreiber N, Herkal A, Anand A, Bastos D, Heller G, Fleisher M and Scher HI: Clinical validity of detecting circulating tumor cells by AdnaTest assay compared with direct detection of tumor mRNA in Stabilized whole blood, as a biomarker predicting overall survival for metastatic castration-resistant prostate cancer patients. Cancer J 22: 315-320, 2016.

88. Cattrini C, Rubagotti A, Zinoli L, Cerbone L, Zanardi E, Capaia M, Barboro P and Boccardo F: Role of Circulating Tumor Cells (CTC), Androgen Receptor Full Length (AR-FL) and Androgen Receptor Splice Variant 7 (AR-V7) in a prospective cohort of castration-resistant metastatic prostate cancer patients. Cancers (Basel) 11: pii: E1365, 2019.

89. Vilhav C,Engstrom C,Naredi P,Novotny A,Bourghardt-FagmanJ, Iresjö BM, Asting AG and Lundholm K: Fractional uptake of circulating tumor cells into liver-lung compartments during curative resection of periampullary cancer. Oncol Lett 16: 6331-6338, 2018 
90. Stott SL, Lee RJ, Nagrath S, Yu M, Miyamoto DT, Ulkus L, Inserra EJ, Ulman M, Springer S, Nakamura Z, et al: Isolation and characterization of circulating tumor cells from patients with localized and metastatic prostate cancer. Sci Transl Med 2: 25ra23, 2010.

91. Stott SL, Hsu CH, Tsukrov DI, Yu M, Miyamoto DT, Waltman BA, Rothenberg SM, Shah AM, Smas ME, Korir GK, et al: Isolation of circulating tumor cells using a microvortex-generating herringbone-chip. Proc Natl Acad Sci USA 107: 18392-18397, 2010.

92. Wang S, Thomas A, Lee E, Yang S, Cheng X and Liu Y: Highly efficient and selective isolation of rare tumor cells using a microfluidic chip with wavy-herringbone micro-patterned surfaces. Analyst 141: 2228-2237, 2016

93. He Y, Shi J, Shi G, Xu X, Liu Q, Liu C, Gao Z, Bai J and Shan B: Using the new CellCollector to capture circulating tumor cells from blood in different groups of pulmonary disease: A Cohort Study. Sci Rep 7: 9542, 2017.

94. Tao L, Su L, Yuan C, Ma Z, Zhang L, Bo S, Niu Y, Lu S and Xiu D: Postoperative metastasis prediction based on portal vein circulating tumor cells detected by flow cytometry in periampullary or pancreatic cancer. Cancer Manag Res 11: 7405-7425, 2019.

95.Paoletti C and Hayes DF: Circulating tumor cells. Adv Exp Med Biol 882: 235-258, 2016

96. Wang Z, Sun N, Liu H, Chen C, Ding P, Yue X, Zou H, Xing $C$ and Pei R: High efficiency isolation and rapid identification of heterogeneous circulating tumor cells (CTCs) Using Dual-antibody-modified Fluorescent-magnetic-nanoparticles. ACS Appl Mater Interfaces 11: 39586-39593, 2019.

97. Wei T, Zhang X, Zhang Q, Yang J, Chen Q, Wang J, Li X, Chen J, Ma T, Li G, et al: Vimentin-positive circulating tumor cells as a biomarker for diagnosis and treatment monitoring in patients with pancreatic cancer. Cancer Lett 452: 237-243, 2019.

98. Watanabe T, Okumura T, Hirano K, Yamaguchi T, Sekine S, Nagata $\mathrm{T}$ and Tsukada K: Circulating tumor cells expressing cancer stem cell marker CD44 as a diagnostic biomarker in patients with gastric cancer. Oncol Lett 13: 281-288, 2017.

99. Andree KC, Mentink A, Zeune LL, Terstappen LWMM, Stoecklein NH, Neves RP, Driemel C, Lampignano R, Yang L, Neubauer $\mathrm{H}$, et al: Toward a real liquid biopsy in metastatic breast and prostate cancer: Diagnostic LeukApheresis increases CTC yields in a European prospective multicenter study (CTCTrap). Int J Cancer 143: 2584-2591, 2018.

100. Soler A, Cayrefourcq L, Mazel M and Alix-Panabieres C: EpCAM-independent enrichment and detection of viable circulating tumor cells using the EPISPOT Assay. Methods Mol Biol 1634: 263-276, 2017.

101. Chen F, Wang S, Fang Y, Zheng L, Zhi X, Cheng B, Chen Y, Zhang C, Shi D, Song H, et al: Feasibility of a novel one-stop ISET device to capture CTCs and its clinical application. Oncotarget 8: 3029-3041, 2017.

102.Li M, Lu Y, Long Z, Li M, Kong J, Chen G and Wang Z: Prognostic and clinicopathological significance of circulating tumor cells in osteosarcoma. J Bone Oncol 16: 100236, 2019.

103. Chudasama D, Barr J, Beeson J, Beddow E, McGonigle N, Rice A, Nicholson A and Anikin V: Detection of circulating tumour cells and survival of patients with Non-small cell lung cancer. Anticancer Res 37: 169-173, 2017.

104. Vetter M, Landin J, Szczerba BM, Castro-Giner F, Gkountela S, Donato C, Krol I, Scherrer R, Balmelli C, Malinovska A, et al: Denosumab treatment is associated with the absence of circulating tumor cells in patients with breast cancer. Breast Cancer Res 20: 141, 2018

105. Naoe M, Kusaka C, Ohta M, Hasebe Y, Unoki T, Shimoyama H, Nakasato T, Oshinomi K, Morita J, Fuji K, et al: Developmen of a highly sensitive technique for capturing renal cell cancer circulating tumor cells. Diagnostics (Basel) 9: pii: E96, 2019.

106. Koh Y, Yagi S, Akamatsu H, Kanai K, Hayata A, Tokudome N, Akamatsu K, Higuchi M, Kanbara H, Nakanishi M, et al: Heterogeneous expression of programmed death Receptor-ligand 1 on circulating tumor cells in patients with lung cancer. Clin Lung Cancer 20: 270-277.e1, 2019.

107.Kallergi G, Politaki E, Alkahtani S, Stournaras C and Georgoulias V: Evaluation of isolation methods for circulating tumor cells (CTCs). Cell Physiol Biochem 40: 411-419, 2016

108. Rosenberg R, Gertler R, Friederichs J, Fuehrer K, Dahm M, Phelps R, Thorban S, Nekarda H and Siewert JR: Comparison of two density gradient centrifugation systems for the enrichment of disseminated tumor cells in blood. Cytometry 49: 150-158, 2002.
109. Gascoyne PR, Noshari J, Anderson TJ and Becker FF: Isolation of rare cells from cell mixtures by dielectrophoresis. Electrophoresis 30: 1388-1398, 2009.

110. Di Trapani M, Manaresi N and Medoro G: DEPArray ${ }^{\mathrm{TM}}$ system: An automatic image-based sorter for isolation of pure circulating tumor cells. Cytometry A 93: 1260-1266, 2018.

111. He G, Feng J, Zhang A, Zhou L, Wen R, Wu J, Yang C, Yang J, Li C, Chen D, et al: Multifunctional branched nanostraw-electroporation platform for intracellular regulation and monitoring of circulating tumor cells. Nano Lett 19: 7201-7209, 2019.

112. Li Q, Cui S, Xu Y, Wang Y, Jin F, Si H, Li L and Tang B: Consecutive sorting and phenotypic counting of CTCs by an optofluidic flow cytometer. Anal Chem 91: 14133-14140, 2019.

113. Galanzha EI, Menyaev YA, Yadem AC, Sarimollaoglu M, Juratli MA, Nedosekin DA, Foster SR, Jamshidi-Parsian A, Siegel ER, Makhoul I, et al: In vivo liquid biopsy using Cytophone platform for photoacoustic detection of circulating tumor cells in patients with melanoma. Sci Transl Med 11: pii: eaat5857, 2019.

114. Chu CH, Liu R, Ozkaya-Ahmadov T, Boya M, Swain BE, Owens JM, Burentugs E, Bilen MA, McDonald JF and Sarioglu AF: Hybrid negative enrichment of circulating tumor cells from whole blood in a 3D-printed monolithic device. Lab Chip 19: 3427-3437, 2019.

115. Riethdorf S, O'Flaherty L, Hille C and Pantel K: Clinical applications of the CellSearch platform in cancer patients. Adv Drug Deliv Rev 125: 102-121, 2018.

116. Wang ZL, Zhang P, Li HC, Yang XJ, Zhang YP, Li ZL, Xue L, Xue YQ, Li HL, Chen Q and Chong T: Dynamic changes of different phenotypic and genetic circulating tumor cells as a biomarker for evaluating the prognosis of RCC. Cancer Biol Ther 20: 505-512, 2019.

117. Alix-Panabieres C: EPISPOT assay: Detection of viable DTCs/CTCs in solid tumor patients. Recent Results Cancer Res 195: 69-76, 2012.

118. Krawczyk N, Meier-Stiegen F, Banys M, Neubauer H, Ruckhaeberle E and Fehm T: Expression of stem cell and epithelial-mesenchymal transition markers in circulating tumor cells of breast cancer patients. Biomed Res Int 2014: 415721, 2014.

119. Babayan A, Alawi M, Gormley M, Müller V, Wikman H, McMullin RP, Smirnov DA, Li W, Geffken M, Pantel K and Joosse SA: Comparative study of whole genome amplification and next generation sequencing performance of single cancer cells. Oncotarget 8: 56066-56080, 2016.

120. Gkountela S, Castro-Giner F, Szczerba BM, Vetter M, Landin J, Scherrer R, Krol I, Scheidmann MC, Beisel C, Stirnimann CU, et al: Circulating tumor cell clustering shapes DNA methylation to enable metastasis seeding. Cell 176: 98-112. e14, 2019.

121. Wang Y, Waters J, Leung ML, Unruh A, Roh W, Shi X, Chen K, Scheet P, Vattathil S, Liang $\mathrm{H}$, et al: Clonal evolution in breast cancer revealed by single nucleus genome sequencing. Nature 512: 155-160, 2014.

122. Fehm T, Sagalowsky A, Clifford E, Beitsch P, Saboorian H, Euhus D, Meng S, Morrison L, Tucker T, Lane N, et al: Cytogenetic evidence that circulating epithelial cells in patients with carcinoma are malignant. Clin Cancer Res 8: 2073-2084, 2002

123. Amantini C, Morelli MB, Nabissi M, Piva F, Marinelli O, Maggi F, Bianchi F, Bittoni A, Berardi R, Giampieri R and Santoni G: Expression profiling of circulating tumor cells in pancreatic ductal adenocarcinoma patients: Biomarkers predicting overall survival. Front Oncol 9: 874, 2019.

124. Sinkala E, Sollier-Christen E, Renier C, Rosàs-Canyelles E, Che J, Heirich K, Duncombe TA, Vlassakis J, Yamauchi KA, Huang $\mathrm{H}$, et al: Profiling protein expression in circulating tumour cells using microfluidic western blotting. Nat Commun 8: 14622, 2017.

125. Spitzer MH and Nolan GP: Mass cytometry: Single cells, many features. Cell 165: 780-791, 2016.

126. Del Ben F, Turetta M, Celetti G, Piruska A, Bulfoni M, Cesselli D, Huck WT and Scoles G: A method for detecting circulating tumor cells based on the measurement of single-cell metabolism in droplet-based microfluidics. Angew Chem Int Ed Engl 55: 8581-8584, 2016.

127. Cayrefourcq L, Mazard T, Joosse S, Solassol J, Ramos J, Assenat E, Schumacher U, Costes V, Maudelonde T, Pantel K and Alix-Panabières $\mathrm{C}$ : Establishment and characterization of a cell line from human circulating colon cancer cells. Cancer Res 75: 892-901, 2015. 
128. Yu M,Bardia A, Aceto N, Bersani F, Madden MW, Donaldson MC, Desai R, Zhu H, Comaills V, Zheng Z, et al: Cancer therapy. Ex vivo culture of circulating breast tumor cells for individualized testing of drug susceptibility. Science 345: 216-220, 2014

129.Zhang L, Ridgway LD, Wetzel MD, Ngo J, Yin W, Kumar D, Goodman JC, Groves MD and Marchetti D: The identification and characterization of breast cancer CTCs competent for brain metastasis. Sci Transl Med 5: 180ra148, 2013.

130. Chen Y, Li S, Li W, Yang R, Zhang X, Ye Y, Yu J, Ye L and Tang W: Circulating tumor cells undergoing EMT are poorly correlated with clinical stages or predictive of recurrence in hepatocellular carcinoma. Sci Rep 9: 7084, 2019.

131. Shishido SN, Carlsson A, Nieva J, Bethel K, Hicks JB Bazhenova L and Kuhn P: Circulating tumor cells as a response monitor in stage IV non-small cell lung cancer. J Transl Med 17: 294, 2019.

132. Boral D, Vishnoi M, Liu HN, Yin W, Sprouse ML, Scamardo A, Hong DS, Tan TZ, Thiery JP, Chang JC and Marchetti D: Molecular characterization of breast cancer CTCs associated with brain metastasis. Nat Commun 8: 196, 2017.

133. Scher HI, Graf RP, Schreiber NA, Jayaram A, Winquist E, McLaughlin B, Lu D, Fleisher M, Orr S, Lowes L, et al: Assessment of the validity of Nuclear-localized androgen receptor splice Variant 7 in circulating tumor cells as a predictive biomarker for Castration-resistant prostate cancer JAMA Oncol 4: 1179-1186, 2018.

134.Heller G, McCormack R, Kheoh T, Molina A, Smith MR, Dreicer R, Saad F, de Wit R, Aftab DT, Hirmand M, et al: Circulating tumor cell number as a response measure of prolonged survival for metastatic castration-resistant prostate cancer: A comparison with prostate-specific antigen across five randomized phase III clinical trials. J Clin Oncol 36: 572-580, 2018 .

135. Gao D, Vela I, Sboner A, Iaquinta PJ, Karthaus WR, Gopalan A, Dowling C, Wanjala JN, Undvall EA, Arora VK, et al: Organoid cultures derived from patients with advanced prostate cancer. Cell 159: 176-187, 2014.

136.Zhang Z, Shiratsuchi H, Lin J, Chen G, Reddy RM, Azizi E, Fouladdel S, Chang AC, Lin L and Jiang H: Expansion of CTCs from early stage lung cancer patients using a microfluidic co-culture model. Oncotarget 5: 12383-12397, 2014.

137. Hochmair M, Rath B, Klameth L, Ulsperger E, Weinlinger C, Fazekas A, Plangger A, Zeillinger R and Hamilton G: Effects of salinomycin and niclosamide on small cell lung cancer and small cell lung cancer circulating tumor cell lines. Invest New Drugs: Aug 24, 2019 (Epub ahead of print).

138. Hodgkinson CL, Morrow CJ, Li Y, Metcalf RL, Rothwell DG, Trapani F, Polanski R, Burt DJ, Simpson KL, Morris K, et al: Tumorigenicity and genetic profiling of circulating tumor cells in small-cell lung cancer. Nat Med 20: 897-903, 2014.
139. Vishnoi M, Boral D, Liu H, Sprouse ML, Yin W, Goswami-Sewell D, Tetzlaff MT, Davies MA, Oliva ICG and Marchetti D: Targeting USP7 identifies a metastasis-competent state within bone marrow-resident melanoma CTCs. Cancer Res 78: 5349-5362, 2018

140. Vishnoi M, Liu NH, Yin W, Boral D, Scamardo A, Hong D and Marchetti D: The identification of a TNBC liver metastasis gene signature by sequential CTC-xenograft modeling. Mol Oncol 13: 1913-1926, 2019.

141. Wang D, Yang Y, Jin L, Wang J, Zhao X, Wu G, Zhang J, Kou T, Yao $\mathrm{H}$ and Zhang Z: Prognostic models based on postoperative circulating tumor cells can predict poor tumor recurrence-free survival in patients with stage II-III colorectal cancer. J Cancer 10: 4552-4563, 2019.

142. Takeda K, Yamada T, Takahashi G, Iwai T, Ueda K, Kuriyama S, Koizumi M, Matsuda A, Shinji S, Ohta R, et al: Analysis of colorectal cancer-related mutations by liquid biopsy: Utility of circulating cell-free DNA and circulating tumor cells. Cancer Sci 110: 3497-3509, 2019

143. Sharp A, Welti JC, Lambros MBK, Dolling D, Rodrigues DN, Pope L, Aversa C, Figueiredo I, Fraser J, Ahmad Z, et al: Clinical utility of circulating tumour cell androgen receptor splice Variant-7 status in metastatic Castration-resistant prostate cancer. Eur Urol 76: 676-685, 2019.

144. Ito M, Horimoto Y, Tokuda E, Murakami F, Uomori T, Himuro T, Nakai K, Orihata G, Iijima K and Saito M: Impact of circulating tumour cells on survival of eribulin-treated patients with metastatic breast cancer. Med Oncol 36: 89, 2019.

145. Rossi G, Mu Z, Rademaker AW, Austin LK, Strickland KS, Costa RLB, Nagy RJ, Zagonel V, Taxter TJ, Behdad A, et al: Cell-free DNA and circulating tumor cells: Comprehensive liquid biopsy analysis in advanced breast cancer. Clin Cancer Res 24: 560-568, 2018.

146. Del Re M, Marconcini R, Pasquini G, Rofi E, Vivaldi C, Bloise F, Restante G, Arrigoni E, Caparello C, Bianco MG, et al: PD-L1 mRNA expression in plasma-derived exosomes is associated with response to anti-PD-1 antibodies in melanoma and NSCLC. Br J Cancer 118: 820-824, 2018.

147. De Giorgi U, Mego M, Scarpi E, Giordano A, Giuliano M, Valero V, Alvarez RH, Ueno NT, Cristofanilli M and Reuben JM: Association between circulating tumor cells and peripheral blood monocytes in metastatic breast cancer. Ther Adv Med Oncol 11: 1758835919866065, 2019.

148. Kirwan CC, Descamps T and Castle J: Circulating tumour cells and hypercoagulability: A lethal relationship in metastatic breast cancer. Clin Transl Oncol: Aug 31, 2019 (Epub ahead of print). 